\title{
CrimRxiv
}

\section{EASILY OVERSTATED}

John Jay Research and Evaluation Center

Published on: Jan 01, 2020

DOI: $10.21428 / \mathrm{cb} 6 a b 371.8404324 \mathrm{e}$

License: Creative Commons Attribution 4.0 International License (CC-BY 4.0). 
